\title{
An apPlication of PANZAR-Rosse ApProach IN Assessing Banking Sector Competition IN ZIMBABWE
}

\author{
Sanderson Abel* \\ Nelson Mandela Metropolitan University
}

Received: September 2015

\author{
Pierre le Roux" \\ Nelson Mandela Metropolitan University
}

Accepted: April 2016

\begin{abstract}
This paper assesses the level of competition in Zimbabwe's banking sector using the Panzar-Rosse Hstatistic. The H-Statistic has been assessed, using the total revenues regression equation, and applying the panel least square regression model with fixed effects. The $\mathrm{H}$-statistics is estimated at 0.56 , which result is confirmed, using bank random effects and the General methods of moments. The $\mathrm{H}$-statics obtained from the two methods are 0.54 and 0.51 for the random effect and generalised methods of moments, respectively. The results confirm the presence of monopolistic competition. On an annual basis, the results show that the Zimbabwean banking sector is evolving towards perfect competition. There is need for the government to desist from tampering with market forces as this reduces the amount of competition. This study is important, as there are limited studies on the competition of the banking sector in dollarized economies. Dollarized economies are peculiar in that their characteristics differ from non-dollarized economies.
\end{abstract}

Keywords

Panzar- Rosse, Banking competition, Fixed Effects, Generalised methods of Moments, Zimbabwe.

*Mr S Abel is a PhD candidate in the Department of Economics, Nelson Mandela Metropolitan University, South Africa. [abelsza.mwale@gmail.com]

\#Prof P le Roux is a professor in the Department of Economics, Nelson Mandela Metropolitan University, South Africa. 


\section{INTRODUCTION}

A competitive banking system is a pre-requisite for effective intermediation between savers and investors. A competitive banking sector can bring about superior innovation, which enhances the variety and quality of financial products. This reduces the price of banking products improving the society's standard of living (Carbo et al. 2009). Competition is also important for effective monetary policy transmission, increasing the speed at which policy interest rates, set by the central bank, transfer through to the banking sector. Competition impacts financial innovation, financial wealth of banks, financial stability and the extent to which small to medium enterprises access affordable financing (Bikker 2010).

There are a number of arguments in favour of banking competition. Banking competition helps foster higher economic growth (Buchs \& Mathiesen 2005). It enhances efficiency as it compels managers to cut down on costs in order to remain profitable (Claessens \& Laeven 2004). Banking competition improves the corporate sector's access to finance, reducing the chances of financial crises (Claessens \& Klingebiel 2001). Banking competition enables banks to satisfy the needs of the public at a reduced social cost. It enhances the efficiency of the production and quality of financial products. Claessens and Laeven (2004) argued that a reduction in the level of competition in the banking sector increases the cost of providing financial services which impedes economic growth.

The study undertakes an empirical assessment of the banking sector competition during the period 2009-2014 using the Panzar and Rosse model (P-R model). The study has three objectives. Firstly, it tests for equilibrium within the Zimbabwean banking sector over the period 2009-2014. Secondly, it assesses the nature of competition. Thirdly, it evaluates how competition evolved during the period 2009-2014. The period 2009-2014 is a period of transition in the Zimbabwean economy. The economy experienced an economic crisis during the period 2000-2008. After encountering a decade long economic decline and hyperinflation environment, the government abandoned the local currency in favour of a number of foreign currencies (multicurrency system) as legal tender. This was meant to foster economic stability. The economy returned to a positive growth trajectory and economic stability with single digit inflation figures. Resultantly, the banking sector experienced growth in deposits, loans and assets. The banking sector also suffered a number of challenges. Among the challenges experienced in the banking sector included limited liquidity, increasing credit risk, introduction of price controls by the government, reduced lines of credit, lack of lender of last resort and difficulties to meet new capital requirements. The banking sector has been shown to be heterogeneous with well capitalized banks and some banks facing difficulties meeting regulatory capital requirements. The banking sector experienced a number of bank failures as a result of inadequate capital, liquidity and insolvency problems. These problems compromised their ability to underwrite enough business with some defaulting on paying out depositors forcing the central bank to close them. These factors motivates for an assessment of competition in the Zimbabwean banking sector.

The eighteen banking institutions included in the study are Commercial Banks, Building Societies and a Savings Bank. Since 2009, banks in Zimbabwe are allowed to venture into any banking activity, which have made the distinction among the three categories blurred. Commercial banks are allowed to venture into mortgage finance which was mostly meant for Building Societies. Building Societies are also involved in the core business of commercial banking. The savings bank is also competing with Building societies and Commercial Banks in mortgage financing and commercial banking activities. 
The rest of the paper is organised as follows; section two gives the overview of the Zimbabwean banking sector. Section three reviews the literature; section four outlines the Panza and Rosse methodology of estimating competition in the banking sector. Section five presents the results of the study followed by the conclusions and recommendations in section six.

\section{OVERVIEW OF THE ZIMBABWEAN BANKING SECTOR}

Zimbabwe abandoned the use of local currency in February 2009 (GoZ 2009) and adopted a basket of currencies in response to macroeconomic turbulence experienced during the period 2000-2008. Cumulatively it is estimated the economy declined by 40 percent between 2000 and 2008. Inflation reached 231 million percent by September 2008. The macroeconomic turbulence resulted in the bank-wide loss of value. Bank balance sheets were severely affected by the hyperinflation, shrinking in real terms because of the losses on an inflation adjusted basis. This was attributed to the highly negative real returns on government securities and high levels of statutory reserves (Chipika \& Malaba 2011). Financial intermediation in the economy declined. Traditional bank lending declined as a result of inefficiencies in the national payment systems, the slowdown in the local currency denomination, loans and declining foreign currency flows into the formal banking sector. Efforts by banks to hedge against inflation through investments in real assets worsened the liquidity and solvency situation.

Following the abandonment of the local currency, the economy experienced economic stability and economic growth. The new economic dispensation brought about a number of challenges and opportunities in the banking sector. TABLE 1 shows that the banking sector was profitable during 2009-2014 though it was less than the profitability experienced between 2004 and 2008. The banking sector profit margins were lower under the multi-currency environment despite higher interest rate margins. The low profitability was a result of economic stability experienced during the multicurrency system and tight bank supervision by the central bank. The profitability of the banking sector increased between 2009 and 2011 as a result of economic growth and increased demand for banking products. Profitability took a downward trend in 2012 and 2013. This was a result of declining growth rates and increased rates of non-performing loans.

TABLE 1 shows that the market share of the top four banks declined during the multi-currency period. This was a result of the policy measures put in place by the central bank and increased product offering by the banks. The policy measures included increasing capital requirements and introducing stringent risk management guidelines. Prior to multi-currency the banking sector had experienced a flight to quality situation where the banking public moved their deposits to established big banks. At the peak of economic crisis, the market share of top four banks reached 97 percent. Post the crisis period, the market share of top four banks declined. The market share of top four banks declined to 45 percent in 2012. This suggest that there has been increased competition in the banking sector after the economy stabilised in 2009.

TABLE I show that the amount of NPLs increased during the multi-currency system. The increase in the amount of NPLs was a result of lending to risky borrowers against the background of increasing competition in the sector. On the other hand banks experienced an increase in insider loans; a sign of deterioration in good corporate governance. 
TABLE 1: Zimbabwe's key financial indicators (2004-12)

\begin{tabular}{|c|c|c|c|c|c|c|c|c|c|}
\hline & 04 & 05 & 06 & 07 & 08 & 09 & 10 & 11 & 12 \\
\hline $\begin{array}{l}\text { Market share of top four } \\
\text { banks }\end{array}$ & 0.54 & 0.53 & 0.44 & 0.43 & 0.97 & 0.56 & 0.48 & 0.43 & 0.45 \\
\hline $\begin{array}{l}\text { Regulatory capital to } \\
\text { risk weighted assets }\end{array}$ & 0.35 & 0.29 & 0.34 & 0.33 & 0.33 & 0.27 & 0.18 & 0.14 & 0.13 \\
\hline NPL to total gross loans & 0.23 & 0.09 & 0.04 & 0.01 & 0.05 & 0.02 & 0.04 & 0.08 & 0.13 \\
\hline Return on assets & 0.12 & 0.14 & 0.19 & 0.13 & 0.25 & 0.01 & 0.02 & 0.02 & 0.02 \\
\hline Return on equity & 0.63 & 0.63 & 0.60 & 0.33 & 0.28 & 0.03 & 0.07 & 0.15 & 0.09 \\
\hline $\begin{array}{l}\text { Interest margin/gross } \\
\text { income }\end{array}$ & 0.12 & 0.21 & 0.14 & 0.45 & 0.22 & 0.14 & 0.24 & 0.35 & 0.35 \\
\hline $\begin{array}{l}\text { Non-interest expenses/ } \\
\text { gross income }\end{array}$ & 0.28 & 0.25 & 0.18 & 0.24 & 0.02 & 0.86 & 0.70 & 0.65 & 0.66 \\
\hline Interest rate spread & 0.29 & 0.27 & 0.45 & 0.21 & 0.31 & 0.03 & 0.06 & 0.09 & 0.09 \\
\hline
\end{tabular}

Source: IMF Article IV

The interest rate margin increased between 2009 and 2012. Interest rate margins account for a growing share of gross income from 12 per cent in 2004 to 35 per cent in 2012. The wide ranging interest spreads among banking institutions reflect the different costs and lending rates charged by banks. International banks have very low costs of funds accounting for their relative ease of mobilising deposits, which can be ascribed to their low risk profiles and access to lines of credit. In contrast, small banks suffered high weighted costs of funds, a symptom of the high costs faced in mobilising funds.

The number of banking institutions decreased from 28 in 2008 to 20 by mid -2014 . The decline in the number of banks was a result of bank failures, consolidations and mergers. Mergers and consolidations were motivated by the need to meet the stringent regulatory capital requirements. The bank failure were caused by poor corporate governance, insolvency and imprudent lending activities (RBZ 2014).

The government instituted a Memorandum of Understanding (MoU) between the central bank and the banks in February 2013 regarding bank charges and interest rates. Effectively the banking sector became controlled. This was motivated by the perception that Banks were charging exorbitant interest rates and bank charges to their clients. The MoU altered the business conditions, the interest rate on deposit and investment accounts, and on overdrafts, loans and advances. The MoU restricted the amount of competition on the pricing front since this was predefined by the memorandum. 


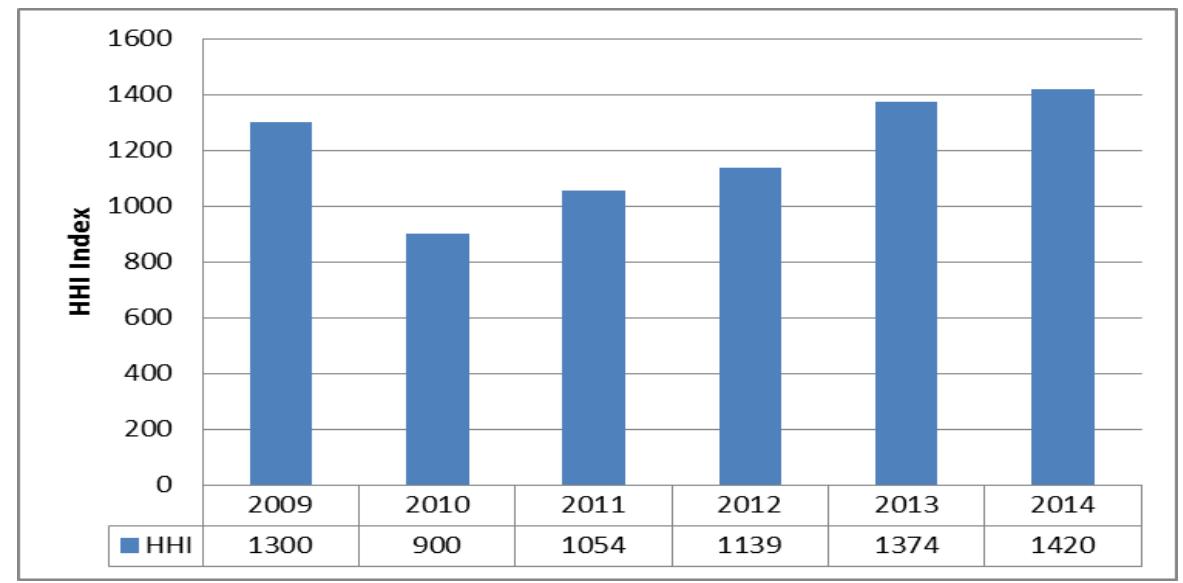

FIGURE 1: Evolution of the HHI

Source: Researcher's own computation

FIGURE 1 shows that the market concentration measured by the Herfindahl-Hirschman Index (HHI) increased between 2009 and 2014. The figure indicates that the index value increased from 1,300 in 2009 to 1,420 as at 31 December 2014 (FIGURE 3). After declining in 2009 and 2010, the $\mathrm{HHI}$ took an upward trend starting from 2011. The highest level of the HHI during the period was experienced in 2014. This implies that the banking sector concentration was increasing from 2012 to 2014 though not by greater margins. This suggest that competition was slightly declining during the period.

\section{LITERATURE REVIEW}

Claessens (2009) identified three approaches to empirical measurement of competition: market structure and associated indicators; contestability and regulatory indicators to gauge contestability; and formal competition measures. The Structure-Conduct-Performance (SCP) paradigm links structure and performance. The market structure is mostly defined by the level of concentration in the market. Conduct relates to the behaviour of the firms in terms of competitiveness or ability to collude. Behaviour takes various forms including pricing, research and development, barriers to entry and technology choice, among others. Performance is mostly defined by market power - market power implying lower efficiency. The SCP argument is that the structure of the industry influences its conduct, which in turn affects performance. For example, if there is low concentration in the industry it will lead to increased competition. Increased competition will lead to reduced market power among the players and improve efficiency. Lower concentration is therefore associated with lower market power. The SCP paradigm is derived from the neo-classical analysis of markets. The initial studies were expanded by including proxy variables for efficiency with the aim of testing the so-called efficient structure hypothesis (Berger 1995). The approach is based on factors such as financial system concentration, the number of banks, or Herfindahl indices.

The contestability and regulatory indicators approach relies on regulatory indicators to gauge the degree of contestability. The method considers regulatory issues such as entry requirements, formal and informal barriers to entry for domestic and foreign banks and 
activity restrictions, among others. The method further takes into account changes over time in financial instruments and innovations, given that these can alter the competition environment. There has been an expansion in the competition determinants with the inclusion of regulatory and institutional variables. Demirgüç-Kunt et al. (2004) investigated the impact of bank-specific characteristics, bank regulations, market structure, and institutional development on bank performance. Barth et al. (2004) examined the relationships between a number of bank regulations and supervisory practices as well as aggregate measures of bank development, performance and stability using a cross-country database.

The formal approach to measuring competition substitutes the reaction of output to input prices. Most of these formal competition measures have been applied in other industries and adopted in measuring banking sector competition. These methods are underpinned by a number of assumptions on cost and production functions. These methods have been developed to circumvent the weaknesses of the SCP. The weakness of the SCP and the efficiency hypotheses is that they assume one way causality from market structure to performance. This means that SCP fails to account for the conduct of the banks in the market and the impact of performance of the banks on market structure. The New Empirical Industrial Organisation (NEIO) methods tried to avoid inferring competition from market shares or market structure but directly inferred firms' conduct using a number of methodologies. This approach uses optimisation models, from which, indicators of competition such as the Lerner index, the Panzar and Rosse test ("H-statistic"), conjectural variation and the Boone indicator are derived.

The Panzar and Rosse $(1982,1987) \mathrm{H}$-statistic measures industry competition based on the elasticity of bank interest revenues to input prices. The approach analyses the transmission of changes in input prices to bank revenue. The approach has been applied by a number of authors (Bikker and Haaf 2002, Gelos and Roldos 2002, Claessens and Laeven 2004, and Levy-Yeyati and Micco 2007). This method falls under approaches classified as non-structural methods that assess competition in respect of new empirical industrial organisations derived from the equilibrium conditions. One of the assumptions underlying the $P-R$ test is that the test only applies for single-output firms. In applying this model to the banking sector, banks are treated as producers of intermediation services by means of factor inputs such as labour, physical and financial capital. The other underlying assumption of the P-R approach relates to the cost structure, which must be homogeneous, and the price elasticity of demand, which must be greater than one.

There are a number of studies that have applied the Panzar-Rosse methodology in measuring the degree of competition in the banking sector (Gelos and Roldos 2002; Nathan and Neave 1989; Claessens and Laeven 2004; De Bandt and Davis 2000; Aktan and Massood 2010). Bikker and Groeneveld (2000) used data from a sample of European countries between 1989 and 1996 and found that there was no competition during the study period. Haffani (2002) studied the structure of Tunisia's banking sector during the period 1980 to 1999 applying the Panzar-Rosse method. The results showed that the Tunisian banking sector operated under monopolistic conditions with increasing competition. Bikker and Haaf (2002) analysed 23 OECD countries over the period 1988 to 1998 and their results showed that the countries were operating in a market structure of monopolistic competition. They further found that competition seemed to be stronger for large banks and weaker for smaller banks.

Weill (2004) studied twelve European countries during the period 1994 to 1999 using the yearly Tobit-based estimates of the $\mathrm{H}$-statistic. The results showed that the countries, e.g. Spain, were 
operating under a decreasing pattern of monopolistic competition. He further found that there was a negative relationship between competition and efficiency. Al-Muharrami et al. (2006) studied the Arab Gulf Cooperation Council's banking sector over the period 1993 to 2002. Using the pooled and the fixed effect method found that the $\mathrm{H}$-statistics was 0.24 and 0.47 respectively. The results meant that the banking sector was operating in a monopolistic competition environment. Wong et al. (2006) studied the evolution of competition in the banking sector of Hong Kong during the period 1991 to 2005 using the Panzar-Rosse method. The results showed that competitive pressure was higher among larger banks and lower among smaller banks.

Korsah, Nyarko and Tagoe (2001) measured the intensity of bank competition in the Ghanaian banking sector after the implementation of economic reforms. The results showed that there was an increase in competition in Ghana's banking system as a result of the economic reforms and the banking sector was oligopolistic in nature, which explained the profitability of the sector. Fu and Heffernan (2009) investigated the relationship between market structure and performance in the Chinese banking system after the reforms in the financial sector. They found that $x$-efficiency significantly decreased and the majority of the banks operated below the levels of efficiencies of effective scale.

Mlambo and Ncube (2011) studied the South African banking sector to ascertain its degree of competition and efficiency. Using the Panzar and Rosse approach, they found that the South African banking sector was operating under monopolistic competition. They further found that the banking sector in South Africa was dominated by five banks which accounted for over 85 per cent of total banking assets. Using a unique and detailed bank-level data set for Zambia, Simpasa (2013) estimated the $\mathrm{H}$-statistic for the Zambian banking sector. The study found the $\mathrm{H}$-statistic to be positive and statistically different from zero and unit. Simpasa (2013) estimated the HStatistic for Zambia at 0.46 implying that Zambian banks earned their revenue under conditions of monopolistic competition.

\section{METHODOLOGY}

This section outlines the methodology and data used in this paper. The model is specified and based on the works by Claessen and Laeven (2004). The model used comprises the prices of the factors of production and bank specific variables. The regression equation to be estimated is outlined in equation 1 :

$$
\operatorname{Ln}\left(R_{i t}\right)=\alpha_{i}+\beta_{1} \ln \left(W_{1, i t}\right)+\beta_{2} \ln \left(W_{2, i t}\right)+\beta_{3} \ln \left(W_{3, i t}\right)+\gamma \ln \left(Z_{, i t}\right)+\varepsilon_{i t}
$$

where $i$ denotes banks and $t$ denotes years. $R_{i t}$ is the ratio of gross revenues to total assets, $W_{1}$, is the ratio of interest expenses to total deposits and money market funding (proxy for input price of deposits), $W_{2}$, is the ratio of personnel expenses to total assets (proxy for input price of labour) and $W_{3}$ is the ratio of other operating and administrative expenses to total assets (proxy for input price of equipment/fixed capital). $Z$ is a matrix of control variables which capture the set of bank specific factors; the ratio of equity to total assets (LETA), the ratio of net loans to total assets (LLTA), and the logarithm of assets to control for bank size (LASS). Finally, $\boldsymbol{\varepsilon}_{\boldsymbol{i}}$ denotes bank-level fixed effects.

The $\mathrm{H}$-statistic is then defined as follows: 
Abel\& Le Roux

$$
H=\beta_{1}+\beta_{2}+\beta_{3}
$$

The interpretation of the $\mathrm{H}$-statistic is shown in TABLE 2.

TABLE 2: H-Statistic interpretation

\begin{tabular}{|c|c|}
\hline H-Value & Interpretation \\
\hline \multirow[t]{3}{*}{$H=0$} & Monopoly Equilibrium \\
\hline & Perfect Colluding Oligopoly \\
\hline & Conjectural variation short run oligopoly \\
\hline $0<H<1$ & Monopolistic competition free entry Equilibrium \\
\hline \multirow[t]{3}{*}{$H=1$} & Perfect competition \\
\hline & Natural monopoly in a perfectly contestable market \\
\hline & Sales maximizing firms subject to break-even constraints \\
\hline
\end{tabular}

Source: Rosse and Panzar (1977, 1982, 1987)

The underlying assumptions of the $P$ - $R$ approach are that it should be used where the observations are in long-run equilibrium. The long-run equilibrium can be tested using the $\mathrm{H}$-statistic in a reduced form equation of profitability. Two measures of profitability, return on assets or return on equity is used in place of the revenue as the dependent variable. The resultant $\mathrm{H}$ is supposed to be significantly equal to zero in equilibrium and significantly negative in the case of disequilibrium. The risk adjusted rates of return in a competitive market will equalise across firms such that rates of return should not be correlated statistically with factor input prices.

To verify the condition of long-run equilibrium, the following regression is estimated:

$$
\begin{aligned}
\operatorname{Ln}\left(R O A_{i t}\right)=\alpha_{i} & +\beta_{1} \ln \left(W_{1, i t}\right)+\beta_{2} \ln \left(W_{2, i t}\right)+\beta_{3} \ln \left(W_{3, i t}\right)+\gamma \ln \left(Z_{, i t}\right) \\
& +\varepsilon_{i t}
\end{aligned}
$$

ROA is the pre-tax return on assets. Because ROA can take on negative values, the dependent variable is computed as $\operatorname{Ln}\left(1+R O A_{i t}\right)$. The equilibrium $\varepsilon$-statistic is defined as follows:

$$
E=\beta_{1}+\beta_{2}+\beta_{3}
$$

The test of long-run equilibrium involves testing whether $E$ is equal to zero. If $E$ is less than zero, there is long-run disequilibrium while if $E$ is equal to zero, there is long-run equilibrium. The test for the long-run equilibrium is undertaken using the Wald coefficient restriction test which tests whether $E$ is equal or less than zero.

A panel data approach is employed to estimate regression equations. The approach is adopted because it is better able to identify and measure effects that are simply not detectable in pure cross-section or pure time series. Panel data allow the construction and testing of more complicated behavioural models than purely cross-sectional or time-series data.

The data used for this study comprise a balanced panel data set collected from the bank reports, websites of the banks, Reserve Bank reports and other sources. The time period chosen for consideration is $2009 \mathrm{Ql}$ to $2014 \mathrm{Q2}$. The time period considered is the multi-currency period when Zimbabwe was using a basket of foreign currencies and the country had abandoned its own 
currency. The time period is important because the country was transitioning from a hyperinflation period to a period of relative stability.

\section{RESULTS PRESENTATION AND ANALYSIS}

TABLE 3 presents the descriptive statistics of the variables under consideration. It shows the average values of the variables, the maximum, minimum and the standard deviation.

The descriptive statistics shows that the data sets have minimal variation as depicted by the low standard deviation. TABLE 4 shows the correlations between all variables under consideration.

The correlation coefficient matrix (TABLE 4) shows that there is no strong correlation among the variables. Gujarati (2007) argued that the problem of multi-collinearity exists if the correlation between independent variables is above 0.8 . All the correlation coefficients between the independent variables were less than 0.8 . As a result all variables were taken into consideration in the estimation of the regression model.

TABLE 5 shows the results for testing for equilibrium in the banking sector.

\section{TABLE 5: Test for equilibrium}

\begin{tabular}{|c|c|c|c|c|c|c|}
\hline \multirow[b]{3}{*}{ Variable } & \multicolumn{3}{|c|}{ Panel least squares with fixed effects } & \multicolumn{3}{|c|}{ GMM } \\
\hline & \multicolumn{3}{|c|}{ Dependent Variable: $\operatorname{Ln}\left(1+R O A_{i t}\right)$} & \multicolumn{3}{|c|}{ Dependent variable: $\operatorname{Ln}\left(1+R O A_{i t}\right)$} \\
\hline & Coef. & $t$-statistic & Prob & Coef. & t-statistic & Prob \\
\hline$C$ & 0.044593 & 0.571779 & 0.5678 & 0.260148 & 1.958800 & 0.0509 \\
\hline $\ln \left(W_{1, i t}\right)$ & 0.000661 & 0.426815 & 0.6698 & -0.005308 & -0.200110 & 0.8415 \\
\hline $\ln \left(W_{2, i t}\right)$ & -0.004748 & -1.476446 & 0.1407 & -0.045484 & -1.762276 & 0.0789 \\
\hline $\ln \left(W_{3, i t}\right)$ & 0.000171 & 0.138552 & 0.8899 & 0.006132 & 0.833846 & 0.4049 \\
\hline LETA & -0.009723 & -1.308228 & 0.1916 & -0.011478 & -0.750835 & 0.4533 \\
\hline LLTA & 0.001128 & 0.391924 & 0.6953 & 0.011826 & 0.465447 & 0.6419 \\
\hline \multirow[t]{3}{*}{ LASS } & -0.007838 & -0.784338 & 0.4333 & -0.050300 & -2.034538 & 0.0426 \\
\hline & \multicolumn{3}{|c|}{$\begin{array}{l}\varepsilon=0.000661+-0.004748+0.000171=- \\
0.003916=0\end{array}$} & \multicolumn{3}{|c|}{$\begin{array}{l}\varepsilon=-0.005308+-0.045484+0.006132=- \\
0.044660\end{array}$} \\
\hline & \multicolumn{3}{|c|}{ Chi-square 1.746421 (0.1863) } & \multicolumn{3}{|c|}{ Chi-square $0.9962(0.3182)$} \\
\hline
\end{tabular}

Source: Researcher's calculations

The P-R model is only valid if the market is in long-run equilibrium. The long-run equilibrium is usually tested with a model in which the dependent variable is return on assets and the independent variables are the same as in the baseline model. The test for the long-run equilibrium was undertaken using the Wald coefficient restriction test. The hypothesis on the long-run equilibrium in the Zimbabwean banking sector is accepted at the 5 percent significance level (TABLE 5). 

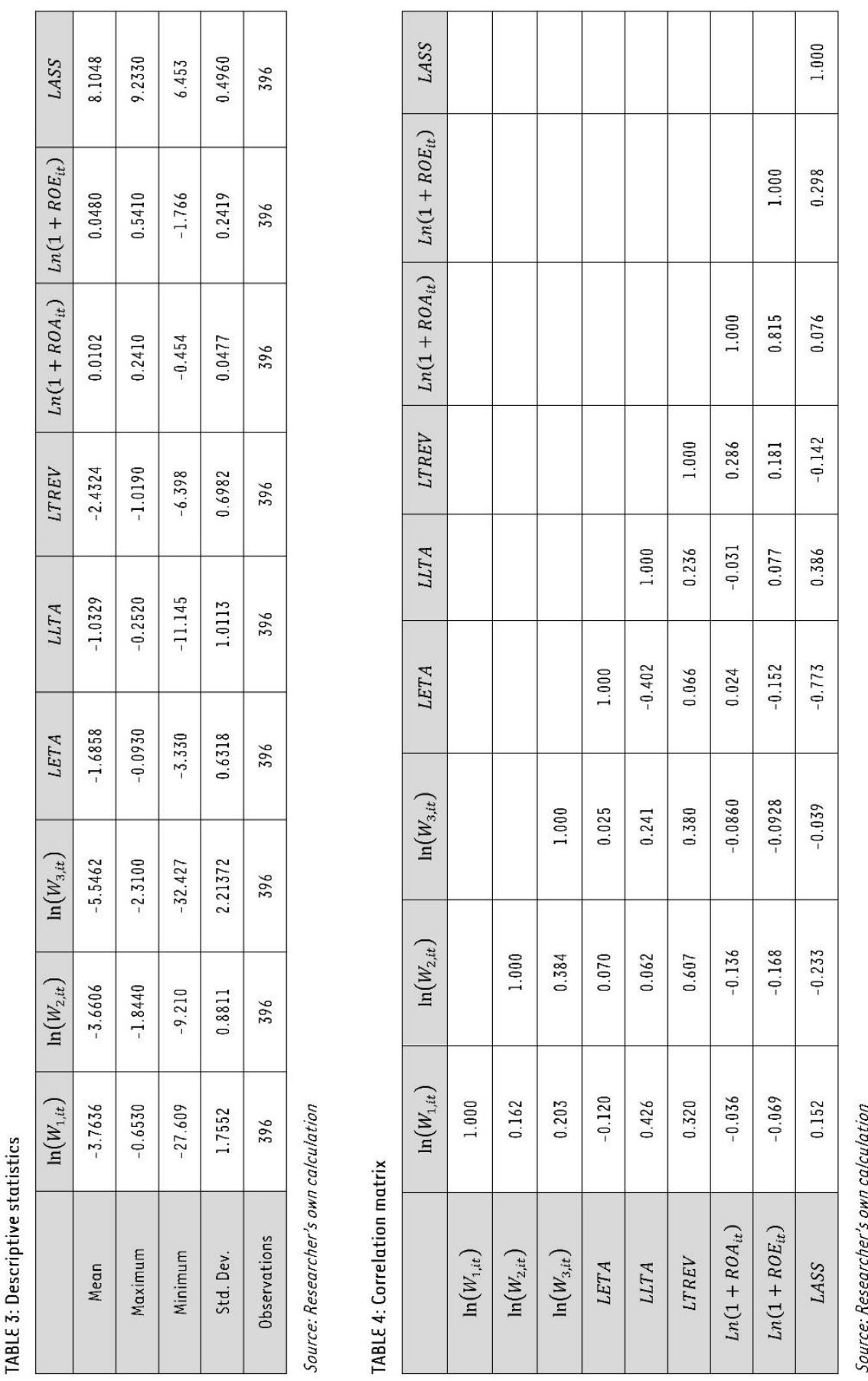
The null hypothesis of the coefficients being equal to zero is accepted confirming that the Zimbabwe banking sector was in equilibrium during the period 2009-2014. The rationale for this test is that, in equilibrium, risk-adjusted rates of return should be equal across banks and returns on bank assets should not be related to input prices.

Based on the Hausman test the random effects model was rejected in favour of fixed effects. This means comparing the coefficients estimated by the fixed and random effects model indicate the fixed effects should be considered as the best fit.

TABLE 6 shows the results for the estimation of the $\mathrm{H}$-statistic for the Zimbabwean banking sector.

TABLE 6: H-Statistic test results: Testing competition

\begin{tabular}{|c|c|c|c|c|c|c|}
\hline \multicolumn{7}{|c|}{ Dependent variable: LTREV } \\
\hline & \multicolumn{3}{|c|}{ Fixed effect } & \multicolumn{3}{|c|}{$G M M$} \\
\hline Variable & Coef. & $t$-stat & $p$-value & Coef. & $t$-stat & $p$-value \\
\hline $\boldsymbol{C}$ & 0.8739 & 0.9539 & 0.3407 & 0.2448 & 0.3933 & 0.6943 \\
\hline $\ln \left(W_{1, i t}\right)$ & 0.0510 & 2.8021 & 0.0053 & 0.0653 & 3.8911 & 0.0001 \\
\hline $\ln \left(W_{2, i t}\right)$ & 0.4739 & 12.5440 & 0.0000 & 0.4070 & 11.9549 & 0.0000 \\
\hline $\ln \left(W_{3, i t}\right)$ & 0.0365 & 2.5173 & 0.0122 & 0.0342 & 2.5750 & 0.0104 \\
\hline LETA & -0.1540 & -1.7647 & 0.0784 & 0.0847 & 1.2494 & 0.2123 \\
\hline LLTA & 0.0871 & 2.5747 & 0.0104 & 0.1078 & 3.3722 & 0.0008 \\
\hline \multirow[t]{5}{*}{ LASS } & -0.1661 & -1.4157 & 0.1577 & -0.0614 & -0.6950 & 0.4875 \\
\hline & \multicolumn{3}{|c|}{ R-squared $=0.538412$} & \multicolumn{3}{|c|}{$H=0.065287+0.406992+0.034202=0.506481$} \\
\hline & \multicolumn{6}{|c|}{ Adjusted R-squared $=0.509873$} \\
\hline & \multicolumn{6}{|c|}{ F-statistic $=18.86579(00000)$} \\
\hline & \multicolumn{6}{|c|}{$H=0.051005+0.473863+0.036543=0.561411$} \\
\hline
\end{tabular}

Source: Researcher's calculations

The estimated $\mathrm{H}$-statistic is 0.56 . The Wald test confirms that the $\mathrm{H}$-statistic is neither zero nor one. This suggest that the banking sector is neither a monopoly nor perfectly competitive. The banking sector can therefore be described as monopolistic competition. Overall, the estimated $\mathrm{H}$-statistic is positive and significant. The results compare favourably with those obtained for Zambia using P-R approach. Simpasa (2013) estimated the H-Statistic for Zambia at 0.46 implying that Zambian banks earned their revenue under conditions of monopolistic competition. This study also found that all the three input prices were positive and significant.

The dependent variable total revenue is positively related to the price of funds $\left(W_{1},\right)$, the cost of labour $\left(W_{2}\right)$ and the cost of capital $\left(W_{3}\right)$. Both the price of funds $\left(W_{1}\right)$ and price of labour $\left(W_{2}\right)$ variables have positive signs, meaning that increased factor costs leading to the higher revenue. All variables $W_{1}, W_{2}$, and $W_{3}$, are statistically significant implying these three variables contribute to the $\mathrm{H}$-statistic.

The equity to assets ratio has a negative but insignificant coefficient. This result contradicts the findings by Simpasa (2013) who found a negative and significant coefficient in the study of the 
Zambian Banking sector. The study found that a large capital buffer aimed at maintaining banks' solvency imposes opportunity costs on their revenue performance.

The results show that the banking sector in Zimbabwe operates under monopolistic competition consistent with the results from other studies that used the same method. The results of the study are supported by Gutiérrez de Rozas (2007), and Bikker and Haaf (2002) who argue that monopolistic competition is ideal because the banking sector is prone to the existence of product differentiation. Banks sell differentiated products with regard to product quality and promotion. The level of monopolistic competition is reduced as a result of perfect substitutability of the products. This means that banks are able to generate more revenue because of the uniqueness of their features such as brands, image and advertising. Other studies that found the same results are: Haffani (2002) who studied the structure of Tunisia's banking sector during the period 1980 to 1999 employing the Panzar-Rosse method. The results show that the Tunisian banking sector operated in a monopolistic structure with increasing competition. Bikker and Haaf (2002) analysed $230 E C D$ countries over the period 1988 to 1998 and their results showed that the countries were operating in a monopolistic competition environment. They further found that competition seemed to be stronger for large banks and weaker for smaller banks; Weill (2004) studied twelve European countries during the period 1994 to 1999 using the yearly Tobit-based estimates of the $\mathrm{H}$-statistic. The results showed that the banks were operating under a decreasing pattern of monopolistic competition in Spain.

For a robustness check, the process was repeated with the GMM method (TABLE 6). The H-statistics obtained from GMM method is 0.64 . The result confirms that the Zimbabwean banking sector is operating under monopolistic competition. The other variables had the same coefficient signs as those obtained from the panel regression with fixed effects.

TABLE 7: Evolution of the Panzar-Rosse H-statistic (2009-2014)

\begin{tabular}{rrrrrrr}
\hline yEAR & 2009 & 2010 & 2011 & 2012 & 2013 & 2014 \\
\hline H-fixed & 0.4579 & 0.8715 & 0.9507 & 0.9925 & 0.9200 & 0.9928 \\
\hline
\end{tabular}

Source: Researcher's own calculation

TABLE 7 shows the results for the evolution of the Panzar and Rosse $\mathrm{H}$-statistic over the period 2009 to 2014. The analysis of the developments of the Panzar-Rosse H-statistics over the period 2009 to 2014 show that competition has been increasing. There was an increase in competition with the $\mathrm{H}$-statistic increasing from 0.47 in 2009 to 0.99 in 2014. This suggest that competition increased between 2009 and 2014.

The results means that competition was low in 2009, the year when the multicurrency was introduced. In 2009, most of the banks did not have adequate foreign currency assets which restricted their ability to underwrite business. Foreign banks because of their parent companies were able to quickly adjust as there could easily source foreign currency resources. Domestic banks could not compete with foreign banks who had easy access to foreign currencies. The situation was worsened by the lack of the lender of last resort and active interbank market. Domestic banks had to rely on foreign banks for liquidity support. Competition increased as domestic banks started attracting lines of credit and foreign currency deposits. The $\mathrm{H}$-statistic declined from 0.99 in 2012 to 0.92 in 2013. The decline in the $\mathrm{H}$-statistic was a result of the MoU which introduced price controls in the banking sector. The effect of the price controls was to reduce competition in the banking sector reversing the benefits of financial liberalisation. Some 
studies render support to financial reforms. Delis (2012) argue that financial reforms and the quality of institutions are major factors that promote competitive conduct of banks. This means that competition increases with financial sector reforms. Moyo and Nandwa (2014) argue that financial reforms increase the amount of competition which enhances financial innovation and efficiency. Hauner and Peiris (2005) also argue that competition and efficiency leads to financial stability, product innovation and increased access to financial services by households and firms.

\section{CONCLUSION AND RECOMMENDATION}

The study has undertaken an empirical assessment of competition in the Zimbabwean banking sector between 2009 and 2014. The assessment was undertaken using Panzar and Rosse (1977, 1987) P-R model. This method assesses the intensity of competition on the basis of a reduced form equation that explains revenue in terms of factor input prices and other control variables. The objectives of the study was to test for equilibrium in banking sector; assess the nature of competition and evaluate the evolution of competition during the period 2009-2014. The study employed a data set which consisted of a balanced panel of eighteen banks which subsisted during the study period. The results show that the banking sector in Zimbabwe operates under monopolistic competition. The results imply that banks are able to generate more revenue because of the uniqueness of their features such as brands, image and advertising.

The findings indicate that competition has been increasing over the years in the banking sector. In 2009, competition in the banking sector was low with an $\mathrm{H}$-statistic of 0.46 . The intensity of competition started to increase in 2010 as banks adjusted to the new dispensation of multicurrency. The lack of the lender of last resort and active interbank market then meant domestic banks relied on foreign banks and foreign lines of credit for liquidity support. This put foreign owned banks at an advantage in the early years of using multicurrency hence restricting the amount of competition. With time domestic banks were able to attract lines of credit and new clients increasing competition in the banking sector. Since then the intensity of competition has been increasing in the banking sector.

The result have shown that controls limit competition. The results show that the introduction of price controls in 2013 reduced competition in the banking sector. The Memorandum of Understanding which was announced by the government in February 2013, imposed controls on a liberalised banking sector, which weakened the functioning of demand and supply forces. The business conditions, including the interest rates on deposit and investment accounts; on overdrafts, loans and advances were altered. The MoU restricted the amount of competition as these revenue streams were almost predefined by the authorities. The study found that in a liberalised market, government controls distort the pricing and affect the competitiveness of the sector. The government should therefore desist from controlling prices and allow the functioning of market forces.

\section{Acknowledgement}

The authors would like to acknowledge the financial support received from the Economic Research Southern Africa (ERSA). 


\section{LIST OF REFERENCES}

Abdul-Majid, M.Z. \& Sufian, F. (2008). Market structure and competition in emerging markets: Evidence from Malaysian Islamic Banking Industry, MPRA Paper No. 12126.

Aktan, B. \& Masood, 0. (2010). The state of competition of the Turkish Banking Industry: an Application of the Panzar-Rosse Model. Journal of Business Economics and Management, 11(1), pp. 131-145.

Alesina, A. \& Barro, J.J. (2001). Dollarization. The American Economic Review, 91(2), pp. 381-385.

Berger, A.N., Deyoung, R., Flannery, M.J., Lee, D. \& Öztekin, Ö. (2008). How do large banking organisations manage their capital ratios? Journal of Financial Services Res. 34, pp. 123-149.

Al-Muharrami, S., Matthews, K. \& Karbhari, Y. (2006), Market structure and competitive conditions in the Arab GCC banking system. Journal of Banking \& Finance, 30, pp. 3487-3501.

Ariss, R. (2009). Competition behaviour in Middle East and North Africa banking systems. The Quarterly Review of Economics and Finance, 49, pp. 693-710.

Casu, B. \& Molyneux, P. (2003). A comparative study of efficiency in European banking. Applied Economics, Taylor \& Francis Journals, 35(17), pp. 1865-1876.

Barth, J.R., Caprio, G. \& Levine, R. (2004). Bank supervision and regulation: What works best? Journa/ of Financial Intermediation, 13, pp. 205-48.

Bhetuwal, K.R. (2005). Assessing the effectiveness of financial sector reforms in Nepal. Faculty of Arts. Vadodara: Maharaja Sayajirao University of Baroda,

Bikker, J.A. (2010). Measuring performance of banks: An assessment. Journal of applied Business and Economics, 11(4), pp. 141-159.

Bikker, J.A., \& Boss, J.W.B. (2005). Competition and efficiency in banking: International comparisons. Economic \& Financial Modelling, pp.103-139.

Bikker, J.A. \& Groeneveld, J.M. (2000). Competition and concentration in the $\varepsilon U$ banking industry. Kredit und Kapital, 33, pp. 62-98.

Bikker, J.A. \& Haaf, K. (2000). Measures of Competition and Concentration in the Banking Industry: A review of the literature. Research Series Supervision No. 27, DeNederlandsche Bank.

Bogetic, Z. (2000). Full dollarization: Fad or future? Challenge, 43(2), pp. 17-48.

Buchs, T. \& Mathisen, J. (2005). Competition and efficiency in banking: Behavioural evidence from Ghana. IMF Working Paper No. 05/17. Washington: International Monetary Fund.

Ramon, C. \& Matutes, C. (2002). Market power and bank failures. International Journal of Industrial Organisation, 20(9), pp. 1341-1361.

Carbo, S., Humphrey, D., Maudos, J. \& Molyneux, P. (2009). Cross-country comparisons of competition and pricing power in European banking. Journal of International Money and Finance, 28, pp. 115-134.

Chipika, J.T. \& Malaba, J. (2011). Indigenization and economic empowerment study. Harare: Business Council of Zimbabwe.

Chirwa, E.W. (2003). Determinants of commercial banks' profitability in Malawi: A co-integration approach. Applied Financial Economics, 13, pp. 565-571. 
Claessens, S. (2009) Competition in the financial sector: Overview of competition policies. IMF Working Paper. No. 09/45.

Claessens, S. \& Laeven, L. (2004). What drives bank competition? Some international evidence? Journal of Money, Credit and Banking, 36, pp. 562-583.

Claessens, S. \& Klingebiel, D. (2001). Competition and scope of activities in financial services. The World Bank Research Observer, 16(1), pp. 19-40.

Cooray, A. (2003). Financial reform: Evidence from Sri Lanka. Proceedings of the Fifth Conference on Money and Finance, IGIDR. Mumbai, India.

De Bandt, 0. \& Philip Davis, દ. (2000). Competition, contestability and market structure in European banking sectors on the eve of EMU. Journal of Banking and Finance 24, pp. 1045-1066.

Delis, M. (2012). Bank competition, financial reform and institution. The importance of being developed economies, 97(2), pp. 450-65.

Demirgüç-Kunt, A., Laeven, L. \& Levine, R. (2004). Regulations, market structure, institutions, and the cost of financial intermediation. Journal of Money, Credit and Banking, 36(2), pp. 593-622.

Yeyati, E.L. 2003. Financial dedollarization: A carrot and stick approach. Business School Working Papers Nueve, Universidad Torcuato Di Tella.

Fu, X.M. \& Heffernan, S. (2009). The effects of reform on China's bank structure and performance. Journal of Banking \& Finance, 33, pp. 39-52.

Gelos, G., \& Roldós, J. (2004). Consolidation and market structure in emerging market banking systems. Emerging Markets Review, 5(1), pp. 39-59.

Hakam, A., Fatine, F.A. \& Zakaria, F. (2012). Determinants of banking competition in Morocco and evaluation of the structural reforms. SSRN.

Hauner, D. \& Peiris, S.J. (2005). Bank efficiency and competition in low-income countries: The case of Uganda. IMF Working Paper, No. 05/240. Washington: International Monetary Fund.

Jiménez, G., Ongena, S., Peydró, J., \& Saurina, J. (2007). Stress-testing the Banking System: Methodologies and applications. Cambridge: Cambridge Press.

Korsah, K., Nyarko, E.K. \& Tagoe, N.A. (2001). Impact of financial sector liberalization on competition and efficiency in the Ghanaian banking industry. International Labor Organisation Research paper, 01-2, 1-51.

Koskela, $\varepsilon$. \& Stenbecka, R. (2000). Bank mergers and the fragility of loan markets. Finnish Economic Papers, 13(1), pp. 3- 18.

Liu, J.S. et al. (2010). Data envelopment analysis 1978-2010: A citation-based literature survey. Elsevier.

Noland, M. (1996). Restructuring Korea's financial sector for greater competitiveness. Working Paper Series, No. 96-14. Peterson Institute for International Economics.

Matutes, C., Vives, X. (2000). Imperfect competition, risk taking and competition in banking. European Economic Review, 44, pp. 1-34.

Moyo, J., Nandwa, B., Oduor, J. \& Simpasa, A. (2014). Financial sector reforms, Competition and banking system stability in Sub-Saharan Africa. Paper presented at the joint RES-SPR Conference on "Macroeconomic Challenges Facing Low-Income Countries". IMF-Washington D.C. 
Nathan, A. \& Neave, E.H. (1987). Competition and contestability in Canada's financial system: Empirical results. Canadian Journal of Economics, 22, pp. 576-94.

Panzar, J.C. \& Rosse, J.N. (1977). Chamberlin versus Robinson: An empirical test for monopoly rents. Bell Laboratories Economic Discussion Paper, No. 92.

Panzar, J.C. \& Rosse, J.N. (1987). Testing for "Monopoly" equilibrium. The Journal of Industrial Economics, 35(4), pp. 443-456.

Poshakwale, S. \& Pian, B. (2009). Banking sector and economic growth in Egypt. African Development Review. 21(3), pp. 435-453.

Quispe-Agnoli, M. \& Whisler, દ. (2006). Official dollarization and the banking system in Ecuador and $\varepsilon$ Salvador. Economic Review Third Quarter, Federal Reserve Bank of Atlanta.

Weill, L. (2003). Banking efficiency in transition economies: The role of foreign ownership. Economics of Transition, 11, pp. 569-592.

Wong, J. (2006). Market structure, competition and intermediation in banking industry. Working paper. Germany: University of Frankfurt.

Yildrimi, S. \& Philippatos, G. (2002). Efficiency of banks: Recent evidence from the transition economics of Europe, 1993-2000. Knoxville: University of Tennessee. Mimeo. 